\title{
Synthesis and spectroscopic properties of $\beta$-triazoloporphyrin-xanthone dyads
}

\author{
Dileep Kumar Singh and Mahendra Nath*
}

\author{
Full Research Paper \\ Address: \\ Department of Chemistry, University of Delhi, Delhi 110 007, India \\ Email: \\ Mahendra Nath ${ }^{*}$ - mnath@chemistry.du.ac.in \\ * Corresponding author \\ Keywords: \\ 1,3-dipolar cycloaddition; fluorescence; synthesis; \\ triazoloporphyrin-xanthone dyads; UV-vis spectroscopy
}

Beilstein J. Org. Chem. 2015, 11, 1434-1440.

doi:10.3762/bjoc.11.155

Received: 03 June 2015

Accepted: 23 July 2015

Published: 17 August 2015

Associate Editor: J. P. Wolfe

(C) 2015 Singh and Nath; licensee Beilstein-Institut.

License and terms: see end of document.

\begin{abstract}
A novel series of $\beta$-triazoloporphyrin-xanthone conjugates and xanthone-bridged $\beta$-triazoloporphyrin dyads has been synthesized in moderate to good yields through $\mathrm{Cu}(\mathrm{I})$-catalyzed Huisgen 1,3-dipolar cycloaddition reaction of copper(II) 2-azido-5, 10,15,20-tetraphenylporphyrin or zinc(II) 2-azidomethyl-5,10,15,20-tetraphenylporphyrin with various alkyne derivatives of xanthones in DMF containing $\mathrm{CuSO}_{4}$ and ascorbic acid at $80{ }^{\circ} \mathrm{C}$. Furthermore, these metalloporphyrins underwent demetalation under acidic conditions to afford the corresponding free-base porphyrins in good to excellent yields. After successful spectroscopic characterization, these porphyrins have been evaluated for their photophysical properties. The preliminary results revealed a bathochromic shift in the UV-vis and fluorescence spectra of these porphyrin-xanthone dyads.
\end{abstract}

\section{Introduction}

In the past few decades, porphyrin macrocycles have emerged as a unique class of heterocyclic compounds and as most attractive building blocks for supramolecular arrays. These molecules provide various desirable properties such as a rigid planar geometry, highly conjugated structures, intense electronic absorption and emission properties and small HOMO-LUMO energy gaps [1,2]. Additionally, the electronic properties of porphyrins can be modulated by introducing diverse functionalities on their periphery or changing the metal ions in the porphyrin core $[3,4]$. Due to the high thermal stability and extended $\pi$-electron system, porphyrins are very useful for the construction of molecular switches $[5,6]$ and other organic photoelectric materials $[7,8]$. In addition, porphyrins are potentially used as photosensitizers in photodynamic therapy to treat various types of tumors $[9,10]$. In recent years, many hybrid molecules including porphyrin- $\mathrm{C}_{60}$ [11], porphyrin-quinones [12] and porphyrin-cyclodextrin [13] conjugates were synthesized and evaluated for their photophysical properties. These compounds have successfully demonstrated the occurrence of an excited electron transfer from the porphyrin subunit to the attached acceptor moieties. On the other hand, some photoinduced electron transfer systems such as porphyrin-tetrathiafulvalenes [14], porphyrin-cyanines [15], porphyrin-carotenes [16], porphyrin-arene diimide [17] and porphyrin-fluorocene or rhodamine [18] have also been synthesized in which the porphyrin unit acts as an electron acceptor. 
Recently, the 1,2,3-triazole scaffold has been successfully employed to connect porphyrins with diverse functionalities such as quinolone [19], ferrocene [20], carbohydrate [21] and fullerene [22] through a copper(I)-catalyzed Huisgen-Sharpless-Meldal 1,3-dipolar cycloaddition reaction $[23,24]$. Some of these triazolo-bridged porphyrin dyads have shown an efficient intramolecular energy transfer between the porphyrin part and the attached subunit. Moreover, the 1,4-disubstituted triazoles are found to be very useful for various applications including modification of cell surfaces [25], synthesis of new glycoproteins [26], specific labeling of virus particles [27] and synthesis of diporphyrin analogues [20,28-30].

Xanthene- $9 H$-ones are an important class of oxygen-containing heterocycles and are mainly found as secondary metabolites in higher plants and microorganisms. The naturally occurring and synthetic xanthones possess diverse pharmacological activities [31-34] including anti-oxidative [35], antihypertensive [36], anti-inflammatory [37] and antiplatelet agents [38]. They have also been used as fluorophores and exhibited good fluorescence properties when attached to a triazole ring $[39,40]$. Owing to the biological significance of porphyrins, 1,2,3-triazoles and xanthones, it was contemplated to incorporate these heterocyclic scaffolds in a single molecular framework to construct novel $\beta$-triazolo-porphyrin-xanthone conjugates and their diporphyrin analogues which may prove useful as photosensitizers for photodynamic therapy applications.

\section{Results and Discussion}

In continuation of our interest to develop new synthetic methods for porphyrin analogues [41-46], we focus our attention on the construction of various novel $\beta$-substituted triazoloporphyrin-xanthone conjugates. For the preparation of these molecules, the alkynes, 3-amino-6-ethynylxanthen-9-one (3), 3-ethynyl-6-nitroxanthen-9-one (4), and 3-ethynyl-6-methoxyxanthen-9-one (5) were synthesized by using the literature procedures [39,40,47-49]. In addition, copper(II) 2-azido5,10,15,20-tetraphenylporphyrin (1) [50] was synthesized in good yield after the treatment of copper(II) 2-amino-5,10,15,20tetraphenylporphyrin with $\mathrm{NaNO}_{2}$ in THF in the presence of $\mathrm{H}_{2} \mathrm{SO}_{4}$ followed by the reaction with $\mathrm{NaN}_{3}$ [28]. The corresponding zinc(II) 2-azidomethyl-5,10,15,20-tetraphenylporphyrin (2) was prepared in $85 \%$ yield from zinc(II) 2-hydroxymethyl-5,10,15,20-tetraphenylporphyrin after the reaction with $\mathrm{NaN}_{3}$ and $\mathrm{BF}_{3} \cdot \mathrm{Et}_{2} \mathrm{O}$ in 1,4-dioxane at $80{ }^{\circ} \mathrm{C}$ for 2 hours [51].

Initially, the copper(II) and zinc(II) derivatives of $\beta$-triazoloporphyrin-xanthone conjugates $\mathbf{6 a}, \mathbf{d}, \mathbf{g}$ and $7 \mathbf{a}, \mathbf{c}$ were synthesized in $60-76 \%$ yields through a copper(I)-catalyzed Huisgen 1,3dipolar cycloaddition reaction between copper(II) 2-azido- 5,10,15,20-tetraphenylporphyrin (1) or zinc(II) 2-azidomethyl5,10,15,20-tetraphenylporphyrin (2) with ethynyl-substituted xanthones $\mathbf{3}, \mathbf{4}$ or $\mathbf{5}$, using copper sulfate and ascorbic acid in $\mathrm{DMF}$ at $80^{\circ} \mathrm{C}$ (Scheme 1). Further, the demetalation of the copper(II) porphyrins $6 \mathbf{6 a , d , g}$ with conc. $\mathrm{H}_{2} \mathrm{SO}_{4}$ at $0{ }^{\circ} \mathrm{C}$ and zinc(II) derivatives 7a,c with conc. $\mathrm{HCl}$ at $25^{\circ} \mathrm{C}$ and neutralization with $5 \%$ aq $\mathrm{NaHCO}_{3}$ afforded the corresponding free-base porphyrins $\mathbf{6 b}, \mathbf{e}, \mathbf{h}$ and $\mathbf{7 b}, \mathbf{d}$, respectively in $78-83 \%$ yields. In addition, the zinc porphyrins $\mathbf{6 c}, \mathbf{f}, \mathbf{i}$ and copper porphyrin $\mathbf{7 e}$ were prepared in $90-93 \%$ yields from free-base porphyrins $\mathbf{6 b}, \mathbf{e}, \mathbf{h}$ and $\mathbf{7 d}$ by their treatment with zinc acetate and copper acetate respectively, in a $\mathrm{CHCl}_{3}-\mathrm{MeOH}$ mixture at room temperature (Scheme 1).

Further, this methodology was extended to the preparation of symmetrical xanthone-bridged triazolodiporphyrins (12a,b and 13a-c). For the synthesis of these compounds, 3,6-diethynylxanthen-9-one (11) was synthesized in three steps from 3,6dihydroxyxanthen-9-one (8) as a starting material. The first step involved the reaction of xanthone $(\mathbf{8})$ with triflic anhydride in $\mathrm{CH}_{2} \mathrm{Cl}_{2}$ containing pyridine at $0{ }^{\circ} \mathrm{C}$ to afford 3,6-di-OTfxanthone [52] (9). Subsequent Sonogashira coupling with trimethylsilylacetylene followed by the deprotection of the trimethylsilyl group in the presence of aqueous $\mathrm{NaOH}$ at room temperature produced the desired product 3,6-diethynylxanthen9-one (11) in 81\% yield (Scheme 2) [39].

Finally, the copper and zinc derivatives of the xanthone-bridged triazolodiporphyrins (12a and 13a) were synthesized in good yields by the "click reaction" of 3,6-diethynylxanthen-9-one (11) with copper and zinc azidoporphyrins, respectively. Further, the free-base diporphyrins $\mathbf{1 2 b}$ and $\mathbf{1 3 b}$ were obtained in $81 \%$ and $84 \%$ yields, respectively after the treatment of $\mathbf{1 2 a}$ with conc. $\mathrm{H}_{2} \mathrm{SO}_{4}$ at $0{ }^{\circ} \mathrm{C}$ and 13 a with conc. $\mathrm{HCl}$ at $25{ }^{\circ} \mathrm{C}$ in chloroform. In addition, the copper(II) bisporphyrin 13c was obtained in almost quantitative yield by reacting the free-base porphyrin 13b with $\mathrm{Cu}(\mathrm{OAc})_{2}$ in a $\mathrm{CHCl}_{3}-\mathrm{MeOH}$ mixture at room temperature (Scheme 3).

All the newly synthesized products were well purified by column chromatography and characterized by NMR, IR, UV-vis and mass spectral data in addition to elemental analyses. The ${ }^{1} \mathrm{H}$ NMR spectrum of xanthone $\mathbf{1 0}$ showed a characteristic singlet of 18 protons at $\delta 0.28 \mathrm{ppm}$ due to trimethylsilyl group which revealed the formation of compound 10. A characteristic singlet of alkyne protons in xanthones 4 and 11 were found at $\delta 4.69 \mathrm{ppm}$ and $\delta 4.66 \mathrm{ppm}$, respectively. In addition, the IR spectra of all the three xanthones 4, 10 and 11 showed a $\mathrm{C} \equiv \mathrm{C}$-bond stretching at around $2100-2157 \mathrm{~cm}^{-1}$ which confirms the attachment of the alkyne moiety to the xanthone core. 


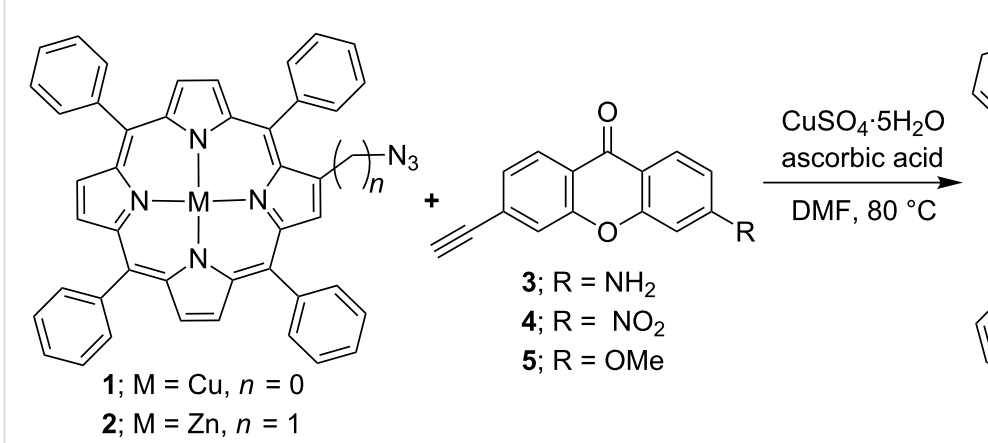

(I)

6a; $\mathrm{M}=\mathrm{Cu}, n=0, \mathrm{R}=\mathrm{NH}_{2}$

6b; $\mathrm{M}=2 \mathrm{H}, n=0, \mathrm{R}=\mathrm{NH}_{2}$ (II)

6c; $\mathrm{M}=\mathrm{Zn}, n=0, \mathrm{R}=\mathrm{NH}_{2}$

(III)

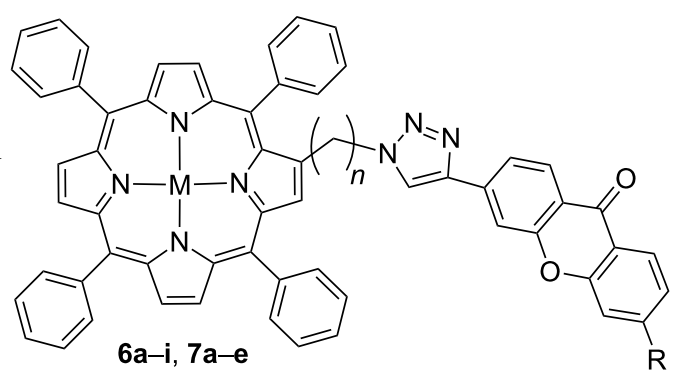

(I)

6d; $\mathrm{M}=\mathrm{Cu}, n=0, \mathrm{R}=\mathrm{NO}_{2}$

$6 \mathrm{e} ; \mathrm{M}=2 \mathrm{H}, n=0, \mathrm{R}=\mathrm{NO}_{2}$

6f; $\mathrm{M}=\mathrm{Zn}, n=0, \mathrm{R}=\mathrm{NO}_{2}$ (II)

(III)

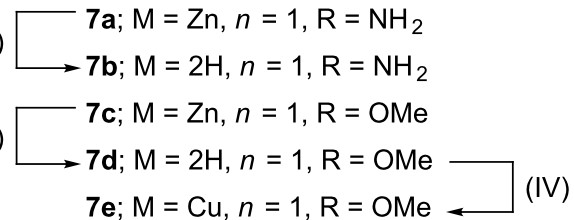

(I)

6g; $\mathrm{M}=\mathrm{Cu}, n=0, \mathrm{R}=\mathrm{OMe}$

6h; $\mathrm{M}=2 \mathrm{H}, n=0, \mathrm{R}=\mathrm{OMe}$

6i; $\mathrm{M}=\mathrm{Zn}, n=0, \mathrm{R}=\mathrm{OMe}$

7e; $\mathrm{M}=\mathrm{Cu}, n=1, \mathrm{R}=\mathrm{OMe}$ (IV)

(I) (a) conc. $\mathrm{H}_{2} \mathrm{SO}_{4}, \mathrm{CHCl}_{3}, \mathrm{O}^{\circ} \mathrm{C}$ (b) aq $\mathrm{NaHCO}_{3}$

(II) $\mathrm{Zn}(\mathrm{OAc})_{2} \cdot 2 \mathrm{H}_{2} \mathrm{O}, \mathrm{MeOH}, \mathrm{CHCl}_{3}, 25^{\circ} \mathrm{C}$

(II) (III) (a) conc. $\mathrm{HCl}, \mathrm{CHCl}_{3}, 25^{\circ} \mathrm{C}$ (b) aq $\mathrm{NaHCO}_{3}$

(IV) $\mathrm{Cu}(\mathrm{OAc})_{2}, \mathrm{MeOH}, \mathrm{CHCl}_{3}, 25^{\circ} \mathrm{C}$

Scheme 1: Synthesis of $\beta$-substituted triazoloporphyrin-xanthone conjugates $6 \mathbf{a}-\mathbf{i}$ and $7 \mathbf{a}-\mathbf{e}$.<smiles>O=c1c2ccc(O)cc2oc2cc(O)ccc12</smiles>
$\underset{0-25^{\circ} \mathrm{C}, \mathrm{CH}_{2} \mathrm{Cl}_{2}}{\stackrel{\mathrm{Tf}_{2} \mathrm{O}, \text { pyridine }}{\longrightarrow}}$

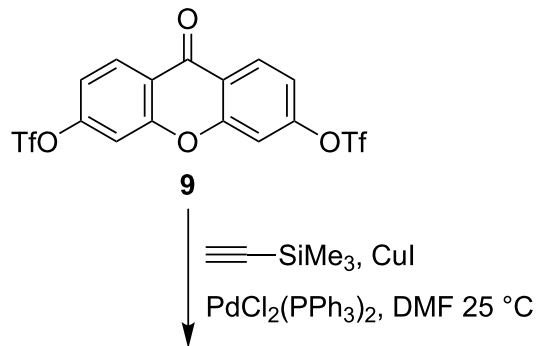<smiles>C#Cc1ccc2c(=O)c3ccc(C#C)cc3oc2c1</smiles>

11

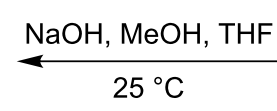

$\frac{\mathrm{NaOH}, \mathrm{MeOH}, \mathrm{THF}}{25^{\circ} \mathrm{C}}$<smiles>C[SiH2]C#Cc1ccc2c(=O)c3ccc(C#CSC)cc3oc2c1</smiles>

Scheme 2: Synthesis of 3,6-diethynyl-xanthen-9-one (11)

In the ${ }^{1} \mathrm{H}$ NMR spectra, $7 \beta$-pyrrolic protons of porphyrin-xanthone conjugates $(\mathbf{6} \mathbf{b}, \mathbf{c}, \mathbf{e}, \mathbf{f}, \mathbf{h}, \mathbf{i}$ and $7 \mathbf{a}-\mathbf{d})$ and 14 $\beta$-pyrrolic protons of bisporphyrins (12b and 13a,b) were found in the down-field region between $\delta 8.44-9.07 \mathrm{ppm}$ as either singlet, doublet or multiplet. The 20 meso-phenyl protons of compounds $\mathbf{6 b}, \mathbf{c}, \mathbf{e}, \mathbf{f}, \mathbf{h}, \mathbf{i}$ and $7 \mathbf{a}-\mathbf{d}$ and the 40 meso-phenyl protons of bisporphyrins $\mathbf{1 2 b}$ and $\mathbf{1 3 a}, \mathbf{b}$ were assigned to doublets and multiplets in the region between $\delta 6.99-8.26 \mathrm{ppm}$. In addition, 6 xanthone protons in the case of all porphyrin-xanthone dyads were found between $\delta 6.47-8.41 \mathrm{ppm}$ as doublet, double doublet or multiplet. A characteristic singlet of two protons at around $\delta-2.7 \mathrm{ppm}$ was assigned for internal $\mathrm{NH}$ protons of the porphyrin core in the case of all the free-base porphyrins. In porphyrins $\mathbf{7 a - d}$ and $\mathbf{1 3 a} \mathbf{a}, \mathbf{b}$, a singlet for the methylene protons was observed between $\delta 5.76-5.82 \mathrm{ppm}$. Similarly, a singlet of three protons due to the presence of methoxy group was observed in the upfield region at $\delta \sim 3.9$ ppm in porphyrins $\mathbf{6 h}, \mathbf{i}$ and $\mathbf{7 c}, \mathbf{d}$. The two protons for the amino group in porphyrins $\mathbf{6 b}$ and $\mathbf{6 c}$ appeared as broad singlet at $\delta 4.33$ and $4.89 \mathrm{ppm}$, respectively, whereas these protons are down-field shifted to $\delta \sim 6.52 \mathrm{ppm}$ in the case of porphyrins $7 \mathbf{a}$ and $\mathbf{7 b}$. The IR spectra of the compounds containing amino 


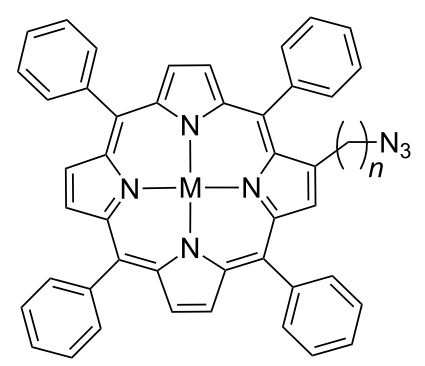

1; $\mathrm{M}=\mathrm{Cu}, n=0$

2; $\mathrm{M}=\mathrm{Zn}, n=1$<smiles>C#Cc1ccc2c(=O)c3ccc(C#C)cc3oc2c1</smiles>

11



12a; $\mathrm{M}=\mathrm{Cu}, n=0 \longrightarrow$ (a) conc. $\mathrm{H}_{2} \mathrm{SO}_{4}, \mathrm{CHCl}_{3}, 0^{\circ} \mathrm{C}$

12b; $\mathrm{M}=2 \mathrm{H}, n=0 \longleftarrow$ (b) aq $\mathrm{NaHCO}_{3}$

(a) conc. $\mathrm{HCl}, \mathrm{CHCl}_{3}, 25^{\circ} \mathrm{C}$

13a; $\mathrm{M}=\mathrm{Zn}, n=1$

(b) aq $\mathrm{NaHCO}_{3}$

13b; $\mathrm{M}=2 \mathrm{H}, n=1$

13c; $\mathrm{M}=\mathrm{Cu}, n=1$ $\mathrm{Cu}(\mathrm{OAc})_{2}, \mathrm{MeOH}, \mathrm{CHCl}_{3}, 25^{\circ} \mathrm{C}$

Scheme 3: Synthesis of xanthone-bridged triazolo-bisporphyrins 12a,b and 13a-c.

groups showed a $\mathrm{NH}_{2}$ bond stretching band between $3348-3433 \mathrm{~cm}^{-1}$, whereas all the free-base porphyrins showed absorptions between $3322-3327 \mathrm{~cm}^{-1}$ due to the internal $\mathrm{NH}$ groups of the porphyrin core. In addition, a strong band was observed at $1602-1654 \mathrm{~cm}^{-1}$ due to the presence of the carbonyl groups in the porphyrin-xanthone dyads. The mass spectra of all compounds further supported the assigned structures by showing a molecular ion peak either as $[\mathrm{M}+\mathrm{H}]^{+}$or $[\mathrm{M}+\mathrm{Na}]^{+}$ or $[\mathrm{M}+\mathrm{K}]^{+}$.

The electronic absorption spectra of all the newly prepared porphyrin-xanthone conjugates were taken in $\mathrm{CHCl}_{3}$ $\left(1.5 \times 10^{-6} \mathrm{M}\right)$ at room temperature. The copper(II) $\beta$-triazoloporphyrin-xanthone conjugates $\mathbf{6 a}, \mathbf{d}, \mathbf{g}$ and 12a exhibited a typical Soret band at around 420-421 nm and two Q-bands at $\sim 544$ and $578 \mathrm{~nm}$, which were found to be red-shifted by about 3-5 $\mathrm{nm}$ as compared to the starting porphyrin $\mathrm{Cu}$-TPP (Soret band at $416 \mathrm{~nm}$ and Q-bands at 541 and $574 \mathrm{~nm}$ ). Further, the free-base $\beta$-triazoloporphyrin-xanthone conjugates $\mathbf{6 b}, \mathbf{e}, \mathbf{h}$ and 12b display their Soret bands at around 424-425 nm and four Q-bands around $\sim 521,556,596$ and $652 \mathrm{~nm}$ which were also red-shifted by about 5-6 nm when compared to the TPP (Soret band at $419 \mathrm{~nm}$ and Q-bands at 516, 551, 590 and $646 \mathrm{~nm}$ ). In addition, zinc(II) $\beta$-triazoloporphyrin-xanthone dyads $\mathbf{6 c}, \mathbf{f}, \mathbf{i}$ exhibited their Soret bands between $430-431 \mathrm{~nm}$ and two Q-bands at $\sim 561$ and $602 \mathrm{~nm}$ which were found to be redshifted by about 5-6 nm as compared to the Zn-TPP (Soret band at $425 \mathrm{~nm}$ and Q-bands at 555 and $597 \mathrm{~nm}$ ). In contrast, zinc(II) $\beta$-triazolomethylporphyrin-xanthone dyads (7a,c,13a), free-base $\beta$-triazolomethylporphyrin-xanthone dyads (7b,d,13b) and copper(II) $\beta$-triazolomethylporphyrin-xanthone dyads $(\mathbf{7 e}, \mathbf{1 3 c})$ exhibited only a $2 \mathrm{~nm}$ red shift in their Soret and Q-bands when compared with the $\mathrm{Zn}$-TPP, TPP and Cu-TPP, respectively. Thus, the electronic absorption spectra of $\beta$-triazoloporphyrin-xanthone conjugates exhibited 2-4 nm red shifts in their Soret and Q-bands as compared to the $\beta$-triazolomethylporphyrin-xanthone conjugates. In addition, the absorption intensity of symmetrical xanthone-bridged $\beta$-triazolodiporphyrins $(\mathbf{1 2 a}, \mathbf{b}$ and $\mathbf{1 3 a}-\mathbf{c})$ was quite larger than their corresponding monoporphyrin-xanthone conjugates. The electronic absorption spectra of copper porphyrins (Cu-TPP, 6a, 7e, 12a and 13c), free-base porphyrins (TPP, $6 b, 7 b, 12 b$ and $\mathbf{1 3 b}$ ), 
and zinc porphyrins (Zn-TPP, 6c, 6f, 7a and 13a) are shown in Figure 1a-c.

Besides the Soret and Q-bands, an additional absorption band was also observed at $\sim 340 \mathrm{~nm}$ in the UV-vis spectra of these porphyrin-xanthone conjugates due to the presence of xanthone moiety (Figure 1a-c) which suggests that there is no significant interaction between the xanthone and porphyrin moieties in the ground state [53-55].

The fluorescence spectra of compounds $\mathbf{6 b}, \mathbf{c}, 7 \mathbf{a}, \mathbf{b}$, and 13a,b depicted in Figure 1d showed two emission bands of free-base porphyrin-xanthone conjugates between $656-725 \mathrm{~nm}$ which are slightly quenched, but red-shifted about $5-10 \mathrm{~nm}$ as compared to the TPP (emission bands at 650 and $715 \mathrm{~nm}$ ). Similarly, the two emission bands of zinc porphyrins were also observed between $607-662 \mathrm{~nm}$ and they were also quenched and red- shifted by about 5-10 nm as compared to the Zn-TPP (emission bands at 602 and $651 \mathrm{~nm}$ ). In contrast, the copper porphyrins did not show any significant emission due to the paramagnetic nature of the $\mathrm{Cu}(\mathrm{II})$ ions [56].

\section{Conclusion}

In summary, we have successfully synthesized and characterized two new alkyne-substituted xanthones, 3-ethynyl-6-nitroxanthen-9-one and 3,6-diethynylxanthen-9-one. In addition, a new series of various $\beta$-triazole-linked porphyrin-xanthone conjugates and xanthone-bridged triazoloporphyrin dyads were synthesized through click chemistry in moderate to good yields. The preliminary photophysical evaluation of these $\pi$-conjugated molecules revealed a bathochromic shift in their electronic absorption and fluorescence spectra as compared to the meso-tetraarylporphyrins. These results are significantly encouraging and henceforth may be useful for the development


Figure 1: (a) Electronic absorption spectra of Cu-TPP, 6a, 7e, 12a and 13c. (b) Electronic absorption spectra of TPP, 6b, 7b, 12b and 13b (c) Electronic absorption spectra of Zn-TPP, 6c, 6f, 7a and 13a in $\mathrm{CHCl}_{3}\left(1.5 \times 10^{-6} \mathrm{~mol} \mathrm{~L}^{-1}\right)$ at $298 \mathrm{~K}$ and inset shows the expanded UV-vis spectra with Q-bands. (d) Fluorescence spectra of porphyrins TPP, Zn-TPP, $\mathbf{6 b}, \mathbf{c}, \mathbf{7 a}$, b, and 13a,b in $\mathrm{CHCl}_{3}\left(1.5 \times 10^{-6} \mathrm{~mol} \mathrm{~L}^{-1}\right)$ at $298 \mathrm{~K}, \lambda_{\mathrm{ex}}=420 \mathrm{~nm}$. 
of new porphyrin materials for various applications including photosensitizers for photodynamic applications.

\section{Supporting Information}

\section{Supporting Information File 1}

Experimental details and characterization data.

[http://www.beilstein-journals.org/bjoc/content/

supplementary/1860-5397-11-155-S1.pdf]

\section{Supporting Information File 2}

${ }^{1} \mathrm{H}$ and ${ }^{13} \mathrm{C}$ NMR spectra of newly synthesized compounds. [http://www.beilstein-journals.org/bjoc/content/ supplementary/1860-5397-11-155-S2.pdf]

\section{Acknowledgements}

This work has been supported by University of Delhi, India under the scheme to strengthen R\&D Doctoral Research Program. We are thankful to CIF, University of Delhi and SAIF, CDRI, Lucknow, India for providing NMR and mass data. Dileep Kumar Singh is grateful to CSIR, New Delhi, India for providing SRF.

\section{References}

1. Perepichka, D. F.; Bryce, M. R. Angew. Chem., Int. Ed. 2005, 44, 5370-5373. doi:10.1002/anie.200500413

2. Ferreira, J. A. B.; Serra, V. V.; Sánchez-Coronilla, A.; Pires, S. M. G.; Faustino, M. A. F.; Silva, A. M. S.; Neves, M. G. P. M. S.; Cavaleiro, J. A. S.; Costa, S. M. B. Chem. Commun. 2013, 49, 8809-8811. doi:10.1039/c3cc44925d

3. Liao, M.-S.; Scheiner, S. J. Chem. Phys. 2002, 117, 205-219. doi:10.1063/1.1480872

4. Yang, L.; Fang, W.; Zhang, Y. Chem. Commun. 2012, 48, 3842-3844. doi:10.1039/c2cc31016c

5. Straight, S. D.; Andréasson, J.; Kodis, G.; Moore, A. L.; Moore, T. A.; Gust, D. J. Am. Chem. Soc. 2005, 127, 2717-2724. doi:10.1021/ja044128i

6. Wallin, S.; Monnereau, C.; Blart, E.; Gankou, J.-R.; Odobel, F.; Hammarström, L. J. Phys. Chem. A 2010, 114, 1709-1721. doi:10.1021/jp907824d

7. Li, L.-L.; Diau, E. W.-G. Chem. Soc. Rev. 2013, 42, 291-304. doi:10.1039/C2CS35257E

8. Li, X.; Liu, L.; Kang, S.-Z.; Mu, J.; Li, G. Appl. Surf. Sci. 2011, 257, 5950-5956. doi:10.1016/j.apsusc.2011.01.058

9. Vicente, M. G. H. Curr. Med. Chem. - Anti-Cancer Agents 2001, 1, 175-194. doi:10.2174/1568011013354769

10. Ethirajan, M.; Chen, Y.; Joshi, P.; Pandey, R. K. Chem. Soc. Rev. 2011, 40, 340-362. doi:10.1039/B915149B

11. Fungo, F.; Milanesio, M. E.; Durantini, E. N.; Otero, L.; Dittrich, T. J. Mater. Chem. 2007, 17, 2107-2112. doi:10.1039/b617944d

12. Banala, S.; Rühl, T.; Wurst, K.; Kräutler, B. Angew. Chem., Int. Ed. 2009, 48, 599-603. doi:10.1002/anie.200804143

13. Králová, J.; Kejík, Z.; Břiza, T.; Poučková, P.; Král, A.; Martásek, P.; Král, V. J. Med. Chem. 2010, 53, 128-138. doi:10.1021/jm9007278
14. Sadaike, S.-i.; Takimiya, K.; Aso, Y.; Otsubo, T. Tetrahedron Lett. 2003, 44, 161-165. doi:10.1016/S0040-4039(02)02474-7

15. Ogawa, K.; Nagatsuka, Y.; Kobuke, Y. J. Porphyrins Phthalocyanines 2011, 15, 678-685. doi:10.1142/S1088424611003616

16. Fungo, F.; Otero, L.; Durantini, E.; Thompson, W. J.; Silber, J. J.; Moore, T. A.; Moore, A. L.; Gust, D.; Sereno, L. Phys. Chem. Chem. Phys. 2003, 5, 469-475. doi:10.1039/b209694c

17. Redmore, N. P.; Rubtsov, I. V.; Therien, M. J. J. Am. Chem. Soc. 2003, 125, 8769-8778. doi:10.1021/ja021278p

18. Sun, X.; Li, D.; Chen, G.; Zhang, J. Dyes Pigm. 2006, 71, 118-122. doi:10.1016/j.dyepig.2005.06.008

19. da C. Santos, F.; Cunha, A. C.; de Souza, M. C. B. V.; Tomé, A. C.; Neves, M. G. P. M. S.; Ferreira, V. F.; Cavaleiro, J. A. S. Tetrahedron Lett. 2008, 49, 7268-7270. doi:10.1016/j.tetlet.2008.10.024

20. Shetti, V. S.; Ravikanth, M. Eur. J. Org. Chem. 2010, 494-508. doi:10.1002/ejoc.200901070

21. Locos, O. B.; Heindl, C. C.; Corral, A.; Senge, M. O.; Scanlan, E. M. Eur. J. Org. Chem. 2010, 1026-1028. doi:10.1002/ejoc.200901292

22. de Miguel, G.; Wielopolski, M.; Schuster, D. I.; Fazio, M. A.; Lee, O. P.; Haley, C. K.; Ortiz, A. L.; Echegoyen, L.; Clark, T.; Guldi, D. M. J. Am. Chem. Soc. 2011, 133, 13036-13054. doi:10.1021/ja202485s

23. Kolb, H. C.; Finn, M. G.; Sharpless, K. B. Angew. Chem., Int. Ed. 2001, 40, 2004-2021. doi:10.1002/1521-3773(20010601)40:11<2004::AID-ANIE2004>3.0.CO ;2-5

24. Kolb, H. C.; Sharpless, K. B. Drug Discovery Today 2003, 8 , 1128-1137. doi:10.1016/S1359-6446(03)02933-7

25. Deiters, A.; Cropp, T. A.; Mukherji, M.; Chin, J. W.; Anderson, J. C.; Schultz, P. G. J. Am. Chem. Soc. 2003, 125, 11782-11783. doi:10.1021/ja0370037

26. Chan, T. R.; Hilgraf, R.; Sharpless, K. B.; Fokin, V. V. Org. Lett. 2004, 6, 2853-2855. doi:10.1021/ol0493094

27. Wang, Q.; Chan, T. R.; Hilgraf, R.; Fokin, V. V.; Sharpless, K. B.; Finn, M. G. J. Am. Chem. Soc. 2003, 125, 3192-3193. doi:10.1021/ja021381e

28. Shen, D.-M.; Liu, C.; Chen, Q.-Y. Eur. J. Org. Chem. 2007, 1419-1422. doi:10.1002/ejoc.200601046

29. Séverac, M.; Le Pleux, L.; Scarpaci, A.; Blart, E.; Odobel, F. Tetrahedron Lett. 2007, 48, 6518-6522. doi:10.1016/j.tetlet.2007.07.049

30. Punidha, S.; Sinha, J.; Kumar, A.; Ravikanth, M. J. Org. Chem. 2008, 73, 323-326. doi:10.1021/jo702018s

31. Vieira, L. M. M.; Kijjoa, A. Curr. Med. Chem. 2005, 12, 2413-2446. doi:10.2174/092986705774370682

32. Sousa, M. E.; Pinto, M. M. M. Curr. Med. Chem. 2005, 12, 2447-2479. doi:10.2174/092986705774370736

33. Pinto, M. M. M.; Sousa, M. E.; Nascimento, M. S. J. Curr. Med. Chem. 2005, 12, 2517-2538. doi:10.2174/092986705774370691

34. Fotie, J.; Bohle, D. S. Anti-Infect. Agents Med. Chem. 2006, 5, 15-31. doi:10.2174/187152106774755563

35. Blanco-Ayala, T.; Lugo-Huitrón, R.; Serrano-López, E. M.; Reyes-Chilpa, R.; Rangel-López, E.; Pineda, B.; Medina-Campos, O. N.; Sánchez-Chapul, L.; Pinzón, E.; Cristina, T.-S.; Silva-Adaya, D.; Pedraza-Chaverrí, J.; Ríos, C.; de la Cruz, V. P.; Torres-Ramos, M. BMC Complementary Altern. Med. 2013, 13, 262-277. doi:10.1186/1472-6882-13-262

36. Wang, L.-W.; Kang, J.-J.; Chen, I.-J.; Teng, C.-M.; Lin, C.-N. Bioorg. Med. Chem. 2002, 10, 567-572. doi:10.1016/S0968-0896(01)00315-7 
37. Librowski, T.; Czarnecki, R.; Czekaj, T.; Marona, H. Medicina (Kaunas) 2005, 41, 54-58.

38. Correia-da-Silva, M.; Sousa, E.; Duarte, B.; Marques, F.; Carvalho, F.; Cunha-Ribeiro, L. M.; Pinto, M. M. M. J. Med. Chem. 2011, 54 , 5373-5384. doi:10.1021/jm2006589

39. Li, J.; Hu, M.; Yao, S. Q. Org. Lett. 2009, 11, 3008-3011. doi:10.1021/ol9010344

40. Li, J.; Yao, S. Q. Org. Lett. 2009, 11, 405-408. doi:10.1021/ol802700w

41. Singh, D. K.; Nath, M. Org. Biomol. Chem. 2015, 13, 1836-1845. doi:10.1039/C4OB02370F

42. Singh, D. K.; Nath, M. Beilstein J. Org. Chem. 2014, 10, 808-813. doi:10.3762/bjoc.10.76

43. Sharma, S.; Nath, M. Beilstein J. Org. Chem. 2013, 9, 496-502. doi:10.3762/bjoc.9.53

44. Bhatt, R. K.; Singh, D. K.; Nath, M. J. Indian Chem. Soc. 2013, 90 , 1493-1496.

45. Sharma, S.; Nath, M. New J. Chem. 2011, 35, 1630-1639. doi:10.1039/c1nj20248k

46. Sharma, S.; Nath, M. Dyes Pigm. 2012, 92, 1241-1249. doi:10.1016/j.dyepig.2011.07.022

47. Chang, Y.-T.; Ahn, Y.-H. Combinatorial fluorescent rosamine library and uses thereof. U.S. Patent. Appl. US 2008/0124751 A1, May 29, 2008.

48. Šebej, P.; Wintner, J.; Müller, P.; Slanina, T.; Al Anshori, J.; Antony, L. A. P.; Klán, P.; Wirz, J. J. Org. Chem. 2013, 78, 1833-1843. doi:10.1021/jo301455n

49. Piazzi, L.; Belluti, F.; Bisi, A.; Gobbi, S.; Rizzo, S.; Bartolini, M.; Andrisano, V.; Recanatini, M.; Rampa, A. Bioorg. Med. Chem. 2007, 15, 575-585. doi:10.1016/j.bmc.2006.09.026

50. Fenwick, D. Azide substituted porphyrins with crosslinking applications for use in photodynamic therapy. Ph.D. Thesis, The University of British Columbia, Canada, 2002.

51. Garg, A. Synthesis and spectroscopic properties of novel $\beta$-functionalized 5,10,15,20-tetraarylporphyrins and diporphyrin analogues. Ph.D. Thesis, University of Delhi, Delhi, India, 2012.

52. Wu, L.; Burgess, K. Org. Lett. 2008, 10, 1779-1782. doi:10.1021/ol800526s

53. Tao, M.; Liu, L.; Liu, D.; Zhou, X. Dyes Pigm. 2010, 85, 21-26. doi:10.1016/j.dyepig.2009.09.012

54. Lazarides, T.; Charalambidis, G.; Vuillamy, A.; Réglier, M.; Klontzas, E.; Froudakis, G.; Kuhri, S.; Guldi, D. M.; Coutsolelos, A. G Inorg. Chem. 2011, 50, 8926-8936. doi:10.1021/ic201052k

55. Zhou, X.; Liu, D.; Wang, T.; Hu, X.; Guo, J.; Weerasinghe, K. C.; Wang, L.; Li, W. J. Photochem. Photobiol., A: Chem. 2014, 274, 57-63. doi:10.1016/j.jphotochem.2013.09.018

56. Szintay, G.; Horváth, A.; Grampp, G. J. Photochem. Photobiol., A 1999, 126, 83-89. doi:10.1016/S1010-6030(99)00130-6

\section{License and Terms}

This is an Open Access article under the terms of the Creative Commons Attribution License

(http://creativecommons.org/licenses/by/2.0), which permits unrestricted use, distribution, and reproduction in any medium, provided the original work is properly cited.

The license is subject to the Beilstein Journal of Organic Chemistry terms and conditions:

(http://www.beilstein-journals.org/bjoc)

The definitive version of this article is the electronic one which can be found at:

doi:10.3762/bjoc. 11.155 